\title{
LINKING LIVELIHOODS WITH CONSERVATION - AN ENTERPRISE- BASED APPROACH TO BIOSPHERE RESERVE MANAGEMENT
}

\author{
SEEMA BHATT \\ Independent Biodiversity Consultant,Kalpavriksh, India
}

Proceedings of the South and Central Asian MAB Meeting of Experts on Environmental Conservation, Management and Research, Hikkaduwa, Sri Lanka 15-18 October 2002

\begin{abstract}
Summary: Over the past two decades, there has been growing frustration with the traditional conservation approach in several parts of the world. This particular approach has followed the 'hands off' philosophy and has attempted to promote conservation by setting aside areas (now known as Protected Areas) at the cost of people who have depended on the rich biodiversity of the same for centuries. The approach has done inordinate harm where such dependencies exist. The challenge then is to seek innovative approaches to conservation, taking into consideration local community needs. Biosphere Reserves are areas where needs of the local community and biodiversity conservation could very well be addressed together. Providing communities an economic incentive to conserve could also provide one way of integrating biodiversity and community needs. There have been some attempts towards this in the past. One such has been that of the Biodiversity Conservation Network (BCN). BCN was initiated to evaluate an 'enterprise-based' approach in the Asia and Pacific regions. This paper attempts to use the BCN model as a case study and analyse how best to apply it in the context of Biosphere Reserves. It also looks at how best an enterprise-based approach to conservation could help in promoting the philosophy of Biosphere Reserves. The paper discusses issues and challenges that emerged in the $B C N$ supported projects, to help devise appropriate strategies for Biosphere Reserves.
\end{abstract}

\section{Introduction}

The concept of Protected Areas (PAs) for the conservation of wild species of fauna and flora has changed drastically since the world's first National Park (Yellowstone in the United States of America) was established in 1872. Here and in other areas, wildiffe was protected against people, and "non-interference, non-exploitation and public access to enjoy nature" was central to this concept. ${ }^{7}$ It has been subsequently realized that in most parts of the world (particularly in the developing countries) where no PA is a completely insular, isolated piece of habitat, and there are people who continue to eke out a living from these areas, this concept has not worked. Incidents of conflicts worldwide are on the increase.

The Biosphere Reserve concept, thus, came into existence as a result of increasing strife in Protected Areas. These areas, today, are addressing perhaps the biggest challenge in conservation, and that is, how best to conserve biodiversity, while still meeting the needs of local communities in a socially and culturally sensitive manner. The idea to develop this "nonconventional" PA first took shape in 1974, 
within the framework of UNESCO's international research programme on Man and the Biosphere (MAB). ${ }^{1}$

This idea evolved over time and three main objectives were attributed to Biosphere Reserves: $i$ ) conservation of biodiversity from the subspecies to landscape level ii) research and monitoring iii) development function to meet the local people's requirements and improve their quality of life. ${ }^{9}$ The focus of Biosphere Reserves became sharper after the World Conference on Biosphere Reserves, held in Seville, in March 1995. Biosphere Reserves have since been looked at as sites linking up conservation with the livelihoods of local communities. Clear-cut criteria for the management of Biosphere Reserves have been laid out, keeping in mind the sustainable development of the region as a whole. Each Biosphere Reserve is now expected to accomplish the following: a) ensure the conservation of biodiversity at all levels b) support culturally, socially and ecologically sustainable economic development of local communities c) promote relevant research, monitoring, education and information exchange. ${ }^{11}$ To carry out these functions, Biosphere Reserves are planned to be divided into three zones: the core zone to ensure the long-term protection of biodiversity with least disturbance. There could be several core zones within a Biosphere Reserve to make certain that all the ecosystems within the region are represented. A buffer zone surrounds or is contiguous to each core area. This area would accommodate activities that help conservation with related research. The area could also have activities such as tourism and education. The outermost area or transition zone could extend into the surrounding human settlements, agricultural fields. This area is specifically meant for a number of stakeholders to work together towards the sustainable development of the area.

Biosphere Reserves have attempted to see how best to reconcile the conservation of biodiversity with ensuring sustainable livelihoods of local communities. These areas are also best equipped to address the three objectives of the Convention on Biological Diversity (CBD) 1992, which are: i) conservation of biological diversity ii) sustainable use of the components of biodiversity iii) fair and equitable sharing of benefits arising out of the utilization of genetic resources. The CBD, perhaps for the first time, looks at biodiversity from the point of view of conservation, use and equitable sharing of benefits, thus acknowledging the relevance of people who depend on biodiversity for subsistence.

Taking into account the objectives of Biosphere Reserves and that of the Convention on Biological Diversity, it is important that integration of the enterprise based approach on management of Biosphere Reserves be looked at in some depth. The philosophy of Biosphere Reserves suggests that these regions allow for the use of resources by local people, allow for management inputs from local people and finally allow for local people to help in the protection of the area. An enterprisebased approach is perhaps an ideal avenue for all this to happen. In the majority of the Indian Biosphere Reserves, the focus is still on providing local people with 
alternative sources of livelihood so as to reduce pressure from these areas, and many of these areas have within them, ecodevelopment projects that are facilitating this. However, very few are actually looking at how to 'sustainably use' the resources of the area and thereby, allow for the local people to have a stake in the management, research and monitoring and protection of the area in question. Over the past few years, the Joint Forest Management (JFM) programme in India has progressed beyond simply meeting the subsistence needs of local communities, to contributing to income generation and improvement of livelihoods, but this is only a spin off, and not a focused approach.

\section{An Enterprise - Based Approach to Conservation}

What is an enterprise-based approach to conservation? This approach allows for the establishment of small enterprises based on natural resources of the area. The approach is based on the premise that if these enterprises are operated by local people, and they are assured that economic and other returns from this business will come back to them, then the people would also support the protection of the area. In other words, biodiversity-based enterprises managed by local communities may provide these communities the right incentive in order to conserve.

Local communities have from time immemorial understood the value of local bio-resources and used them, both for subsistence as well as for commercial purposes. One estimate suggests that over 50 million people living in and around forests in India rely on products from the forest to meet their minimum requirements. Products that are of value commercially, include bamboo, resin, lac, 'tendu' (Diospyros melanoxylon) leaves for beedies (indigenous cigarettes), honey, tasar silk cocoons, fruits, and other non-timber forest produce (NTFP). ${ }^{10}$ The potential for enterprise is tremendous. It is estimated that out of the 16,000 recorded plant species, 3,000 species have products that can be used and out of these 126 are potentially marketable. ${ }^{6}$

NTFP contribute quite significantly to the forestry sector. An FAO study ${ }^{4}$ indicates that the total value of trade in NTFP globally is US\$1,100 million: In India, NTFP's contribution to state forest revenue is about 40 per cent. The Nilgiri Biosphere Reserve is perhaps one of the largest suppliers of NTFP in the country. ${ }^{5}$

The same holds true of products from coastal and marine areas. Coastal and marine resources such as fish, coral and seaweed have been used for various purposes, including for food, housing, health supplements and as medicine. There are many uses of fish and fish products as medicine, pesticide and fertilizer. In the Gulf of Mannar Biosphere Reserve, over 50,000 people in 138 villages and towns, which extend to over five districts, depend directly or indirectly for their livelihoods on the fishing resources of the waters of the Gulf (www.sanctuaryasia.com/takeaction/ detailcampaign.php). A study carried out in the Sundarban Biosphere Reserve, 
reveals that local communities here have several traditional uses for many plants found in the mangrove habitats. Leaf extracts of plants have medicinal value; seeds and bark of many plants are used as fish poison; wood from many mangrove species is used as fuel; many leaves and fruit are edible and highly nutritious and the sap of certain plants are consumed as alcohol. ${ }^{3}$

However, in many areas, which have been protected for their biodiversity, communities have not been allowed to use many of the resources they used earlier. Where use is still permitted, along with sale of some biodiversity products, communities do not get the full incomes they should. They often get collection charges even for products that have a very high market value. There are some products for which appropriate prices have not been established in the market. Sometimes, marketing channels do not even exist.

Another revenue generating by-product from biodiversity-rich areas is tourism. Ideally, what needs to be promoted is 'ecotourism'. This kind of tourism relies on an area of natural beauty, and the revenue generated as a result of this activity is channeled back to the local communities. Commercial tourism has been conducted in areas of natural beauty, the world over, for many years. But most often it has led to antagonism with local communities since they have gained nothing from it. In many PAs where tourism is practiced, tourism caters to tourists, and very often disregards local communities.

There have been some efforts in the past to promote NTFP-based enterprises and ecotourism in some places in India. This paper examines one such attempt, the Biodiversity Conservation Network (BCN), and then discusses how lessons emerging from this could be used in the context of Biosphere Reserves.

\section{Biodiversity Conservation Network (BCN)}

The BCN was a component of the United States-Asia Environmental Partnership (US-AE), funded by the Asia Bureau of the US Agency for International Development (USAID). BCN operated in the Asia and Pacific region for six and a half years (1993-1999). The programme was initiated to achieve two fundamental goals: (i) to pursue enterprise-based strategies to conserve biological diversity at a number of sites across the Asia and Pacific regions; and (ii) to evaluate the effectiveness of these enterprise-oriented approaches for community-based biodiversity conservation. The programme was designed to test a specific, narrowly defined hypothesis that if conservation is to occur, the enterprise must have a direct link to biodiversity, generate benefits, and have a community of stakeholders who can act to counter threats to the biodiversity of the region. Crucial to BCN's mission was an intense monitoring programme, which focused on the biological, sociological and enterprise elements of the project. ${ }^{2}$ 
This approach was tried by the BCN in 20 sites across Asia and the Pacific. Three of these were in India. The following is a brief description of the Indian BCN funded projects.

\section{NTFP in the Biligiri Rangan Hills}

In the Western Ghats of Karnataka, in Southern India, is situated the Biligiri Rangaswamy (BR) Temple Wildlife Sanctuary. BR Hills, being at the confluence of the Western and Eastern Ghats, possess high floral and faunal diversity. The Sanctuary is also home to 4,000 Soligas, an indigenous tribe of the region. The Soligas were traditionally engaged in shifting cultivation and hunting for their subsistence. Their subsistence also depended on a wide range of NTFP.

With the declaration of the area as a wildlife sanctuary in 1974, both shifting cultivation and hunting have been totally banned. The Soligas are still allowed limited harvesting of NTFP. Marketing of a few selected NTFP is carried out through the Large-Scale Adivasi Multipurpose Societies (LAMPS). But this is not adequate and the tribe continues to get very low economic returns from this activity.

The BCN project focused on the sustainable extraction and local processing of three forest products: (i) 'amla' or gooseberry (Emblica officinalis), (ii) wild honey and (iii) some ayurvedic preparations from selected medicinal plants. By processing and improved marketing of amla (into pickles and jams), honey and some medicinal plants, the project has raised the income levels of the Soligas, and has also provided them with an economic incentive to conserve the region's biodiversity. The biological sustainability of each of these products has been examined and a lot of data pertaining to sustainable harvest rates for 'amla' and some of the other NTFP has been generated. As a result of this project, the Soligas have been registered as a society named Sri Biligiri Kiru Aranya Utpadan Samsakara Sangha in 1997. This society focuses its work on the enterprises and decides how the economic returns from the same should be spent. Several partners have worked on this project. These are the University of Massachusetts at Boston (UMB); Tata Energy Research Institute (TERI); Vivekananda Girijana Kalyana Kendra (VGKK); Ashoka Trust for Research in Ecology and the Environment (ATREE) and the Soliga Abhivirudhi Sanghas.

The project still continues and is now being coordinated by ATREE along with VGKK. Honey processed by the Soligas is now marketed under its own brand name. Jams and pickles made from 'amla' are manufactured and are also being sold in the market.

\section{Tasar Silk and Honey in the Garhwal Himalaya}

This project was based in the Garhwal Himalaya in the newly formed State of Uttaranchal. It focused its work on three catchments, Akash Kamini, Nagnath 
Pokhari and Mandal of Ukhimath, and the Pokhari and Dashauli blocks respectively. The project areas lie in what is known as the 'oak belt' which extends from Himachal Pradesh in the western range through Garhwal and Kumaon onto the northwestern range in Nepal in the east. Biologically, the oak belt is extremely important and is also under severe threat.

The Garhwal and Kumaon region is also significant due to the presence of a number of village-based institutions, i.e., Van Panchayats (village forest management committees), Mahila Mangal Dals (village women's organisations) and Yuvak Mangal Dals (village youth organizations). The presence of these have significantly helped in the promotion of this project.

The enterprises in this project focused on oak tasar sericulture and villagebased bee-keeping/honey production. The silkworms for the production of silk are reared on oak leaves, which are sustainably harvested from surrounding oak forests. The sericulture involves reeling and rearing at specified centers in the villages of the project area.

A district-wide company called Chamoli Tasar Udyog Private Limited has been set up to coordinate sericulture operations, facilitate sale of silk and ensure equitable distribution of returns from the enterprise. For honey production, a district-wide company called Dev Bhumi Madhu Udyog Private Limited has been established. The company provides technical assistance and extension support, buys honey from the bee-keepers and refines as well as packages it.

The partners for this project were, Enterprise Works Worldwide (formerly Appropriate Technology International); Appropriate Technology India (AT India); Kumaon University; Chamoli Tasar Pvt. Ltd.; Devbhumi Madhu Pvt.Ltd.; Small Industries Development Bank of India (SIDBI).

AT India continues to work in the area. Today, the tasar silk from oak is being woven and is sold to the retail market. The honey processed locally has acquired the Agmark certification and is sold in the market under its own brand name, Devbhumi Madhu.

\section{Ecotourism in Sikkim}

The state of Sikkim lies in the eastern Himalayan region. The eastern Himalayan region has been designated as one of the biodiversity 'hotspots' of India. Also significant for the state, when this project started, was the fact that the regulations on foreigners had just been removed, facilitating tourism in the region. This project focused on promoting ecotourism at two locations: The Yuksam Dzongri Trekking Trail which lies in the buffer zone of the Khangchendzonga Biosphere Reserve and the Kecheopalri Lake. Both sites have great religious and cultural significance for 
the Sikkimese. The Kecheoplari Lake is considered sacred and is visited by thousands of Sikkimese all year round. The Yuksam-Dzongri Trail, which starts from the village of Yuksam, is part of the sacred landscape called 'Demojong'. The entire valley is considered to be the abode of Sikkim's deities and held in great esteem. ${ }^{8}$

Taking into account the facts that tourism (particularly from foreign tourists) was a comparatively new phenomenon in Sikkim, and the lack of understanding of ecotourism, the project attempted to assist the Government of Sikkim and the Travel Agents Association of Sikkim (TAAS) in developing and marketing ecotourism activities at the two project sites. Four kinds of activities were carried out under this project at both sites: (i) examining threats linked to tourism (ecodegradation, littering, etc.) and promoting activities that will reduce these, e.g reduce fuelwood use; (ii) developing marketing strategies to promote ecotourism in the region; (iii) developing economically profitable enterprise activities for local communities, such as lodge and restaurant operations, guiding, portering, pack animal operation and vegetable production; and (iv) addressing policy issues related to tourism, such as the regulation and control of entry and government's monopoly on transportation.

The project was implemented by The Mountain Institute; G.B. Pant Institute of Himalayan Environment and Development (GBPIHED); Travel Agents Association of Sikkim (TAAS) and The Green Circle (a local NGO). Perhaps one of the most significant achievements of this project has been the emergence of a local NGO at Yuksam called the Khangchendzonga Conservation Committee (KCC). This NGO continues to carry out the work that the project began. It has developed a Code of Conduct for tourists who trek on this route. They have also taken up the job of voluntarily patrolling the trail, thus helping the Forest Department to regulate tourism. The capacity building of various stakeholders in this project has also helped to replicate this elsewhere in the state.

\section{Relevance of the Enterprise-Based Approach to Biosphere Reserves}

Given the philosophy behind Biosphere Reserves, an enterprise-based approach would perhaps work best in these areas. Some of the values of this approach to Biosphere Reserves are discussed below:

\section{Linking Conservation with Sustainable Livelihood}

The Biosphere Reserve concept has, in essence, become one for testing the link between conservation and livelihoods. The enterprise-based approach, then, becomes an important tool to help achieve this objective. More importantly, it promotes the relatively new school of thought of enhancing existing livelihoods in a sustainable way, rather than suggesting alternative ones. Forests that lie within Biosphere Reserves in India, by virtue of the NTFP that they yield, are a source of livelihood for the local communities. It must not be forgotten that these Biosphere Reserves 
also sustain traditional agriculture, which in itself is likely to support tremendous domestic biodiversity. The same applies to marine and coastal areas. By promoting enterprises based on both wild and domesticated biodiversity, this approach will lead to sustainable livelihoods for the local people.

A step in this direction has been taken in the Nilgiri Biosphere Reserve, where a study to look at the "Conservation and Sustainable Utilisation including Forest Enterprise Development of Non Timber Forest Products" has been carried out by the Indian Institute of Forest Management. ${ }^{5}$ All the Indian Biosphere Reserves can also promote ecotourism. Such activities have already been initiated in some of them. The Khangchendzonga Biosphere Reserve is a case in point. This again is a step towards sustainable livelihoods, provided the local communities have a stake in the enterprise.

\section{Creating a Stake for Communities}

If Biosphere Reserves are believed to create a stake for communities that would ultimately lead to conservation, then an enterprise-based approach to conservation may provide the right incentive. Once communities are involved in the enterprises and get benefits from them, they would feel a greater sense of ownership, and could even be encouraged to get involved in the management of the area. Benefits from the enterprises could be both tangible and intangible. Intangible benefits like enhancement of the communities' self esteem also go a long way in creating a stake for the people. There are instances where communities, once empowered, have helped to protect endangered species from poaching, helped combat forest fires and helped in cleaning up of areas.

\section{Research and Monitoring}

Research and monitoring are an important elements in the management of all Biosphere Reserves. Perhaps the biggest challenge of the enterprise-based approach to conservation is to ensure that the enterprise is viable, sustainable and not degrading the ecosystems in question. This implies that relevant research has to be designed and carried out from the beginning. Biosphere Reserves by their very nature carry out this function, and could actually help in strengthening this approach. It is important however, that this research is carried out with local communities and preferably by them, after a certain length of time. Results from research need to be disseminated on a regular basis to ensure that the enterprise is sustainable. Research needs to be designed in such a way that methodologies can be altered if needed, based on results obtained. The need for adaptive management, thus becomes an important part of the enterprise-based approach to conservation within Biosphere Reserves. 
Research carried out within the Indian Biosphere Reserves has not yet been focused on issues like sustainable harvesting. This approach would promote research of this kind, which is actually needed to understand whether harvesting of certain species can be done without destroying it or degrading the ecosystem. Biosphere Reserves would also provide the opportunity to disseminate the results of this research to the larger conservation community through its education and information agenda.

\section{Linking Traditional Ecological Knowledge and Traditional Technologies}

Biosphere Reserves have within them, communities with rich traditional knowledge and traditional technologies which they have used to manage these ecosystems from time immemorial. Traditional knowledge includes knowledge of traditional crop varieties, lesser known plants and animals of food value, medicinal plants and other economic values. ${ }^{9}$ Local communities also have the knowledge of how best to manipulate these systems in response to naturally occurring processes. This knowledge would be of tremendous value to promote an enterprise-based approach to conservation. This approach would also help to provide the link between traditional knowledge and modern systems of management, and help design one with the best elements from both.

It could also help to recognize cultural, spiritual and religious belief systems and understand management on the basis of these systems. The Khangchendzonga Biosphere Reserve, for example, is part of a sacred landscape called 'Demojong', Local communities are keen to promote ecotourism in the area and benefit from it, but whether they will promote a Code of Conduct for tourists which is culturally and religiously sensitive remains to be seen. Any extraneous management system will have to keep this in mind.

\section{Towards an Enterprise-Based Approach in Biosphere Reserves}

An enterprise-based approach raises certain issues that need to be addressed if this system is to be adapted in Biosphere Reserves. Some are discussed here.

Understanding the Community: In reality, no community is a homogenous structure. This has to be understood before beginning any project. It then becomes important to first approach all sections of society and seek their views before embarking on the project. It is also important to ensure that the weaker sections of the community, i.e. women, the poor and underprivileged, participate and get to share benefits of the project equitably.

Building Capacity: Establishing an enterprise and managing it is a complex process. If the community is expected to be part of the establishment and running of such an enterprise, then it is important to first build capacity of the community to handle 
this. Communities may have to be trained in basic, yet vital functions like bookkeeping and accounting. To involve communities in ecotourism related activities, the community members would have to be trained as guides, porters, cooks, etc. There may also be activities where the communities' knowledge would be of tremendous value, and they should be encouraged to share and utilise their knowledge and skills.

Ensuring a Strong Institutional Base: For a community-based enterprise to succeed, there has to be a strong institutional base. In many instances, community institutions may already exist and it would be best to operate through them as opposed to setting up new ones. This is often detrimental to the whole process. There could, however, be an effort towards strengthening existing institutions to enable them to carry out specific activities.

Understanding Markets: For an enterprise-based approach to succeed, it is important to first ascertain the marketability of products to be sold. Markets vary and the entire enterprise may fail if there is no market for a certain product and hence no economic return. Market surveys need to be carried out before setting up the enterprise.

Ensuring a Multi-Disciplinary Approach: An enterprise-approach to conservation is a complex one. There is a need, therefore, to ensure that multiple institutions, with individual strengths are involved in these initiatives. For example, institutions carrying out biological research seldom focus on social issues and vice versa. Ensuring that the enterprise is going to be viable is yet another strength which only certain kinds of institutions can handle. It is thus important that no one institution is burdened with the task of taking this initiative forward, and that several institutions work in a collaborative fashion.

Ensuring Dissemination of Research Results: It is important that results from the ensuing research be discussed with the people concerned and disseminated to all stakeholders for a clearer understanding of issues. This would also ensure that the whole process can be modified to ensure better results if needed. Sharing of information will also ensure that all the stakeholders feel part of the process and contribute when required.

Working towards Legal Support for Biosphere Reserves: Biosphere reserves in India still do not have the adequate legal support they require. The Wildlife (Protection) Act, 1972 does not recognize Biosphere Reserves as a legal category of Protected Area. This approach will get strengthened if Biosphere Reserves are recognized as a legal category by legislation. 


\section{Conclusion}

The twenty-first century presents conservation of biodiversity with challenges, some new and some old. It has however, become clear in the last decade, that conservation is not going to be possible unless local communities who live and depend on this biodiversity are involved in the conservation of it. Biosphere Reserves provide the right opportunity to involve communities and also ensure sustainable livelihoods for them. The enterprise-based approach within Biosphere Reserves would help in strengthening the philosophy of these areas, and vindicating this whole approach to conservation.

\section{References}

1 Batisse M. (1996). Biosphere Reserves and Regional Planning: A Prospective Vision. Nature \& Resources. 32(3):20-30.

2 Bhatt S. (1998). Conservation Through Community Enterprise. In: Communities and Conservation. Natural Resource Management in South and Central Asia. (Eds. A. Kothari, N. Pathak, R. V. Anuradha and B. Taneja.) Sage Publications, New Delhi.

3 Deshmukh S.V. and Choudhury A. (2002). Final Report of the Project. Preparation of Guidelines for Facilitating Decision-Making Process As Well As Ecosystem Management Practices for the Sunderban Biosphere Reserve in India. (Unpublished).

FAO.(1997). State of World's Forests. FAO, Rome, Italy.

IIFM. (2002). Conservation and Sustainable Utilisation Including Community Forest Enterprise Development of Non Timber Forest Products in Nilgiri Biosphere Reserve. Report. IIFM, Bhopal.

6 Maithani G.P. (1996). Management Perspectives of Minor Forest Produce for Sustainability. Oxford \& IBH Publishing Co. Pvt. Ltd., New Delhi, Calcutta.

$7 \quad$ Nicholson M. (1972). What is Wrong with the National Park Movement? Proceedings of Second World Congress on National Parks, IUCN. Gland.

8 Ramakrishnan P. S. (1998). Conserving the Sacred: Ecological and Policy Implications. In: Communities and Conservation. Natural Resource Management in South and Central Asia. (Eds. A. Kothari, N. Pathak, R. V. Anuradha and B.Taneja). Sage Publications, New Delhi. 
9 Ramakrishnan P.S. (2002). Traditional Ecological Knowledge and Managing Biosphere Reserves in South Asia: Conclusions and Recommendations. Executive Summary. In: Traditional Ecological Knowledge and Managing Biosphere Reserves in South Asia. (Eds. P.S.Ramachandran, R.K. Rai, R.P.S. Katwal, S. Mehndiratta). Oxford \& IBH Publishing Co.Pvt.Ltd., New Delhi, Calcutta.

10 Saigal S., Agarwal C. \& Campbell J.Y. (1996). Sustaining Joint Forest Management. The Role of Non-Timber Forest Products. Society for Promotion of Wasteland Development, New Delhi. (Unpublished).

11 UNESCO. (2000). The World Network of Biosphere Reserves. UNESCO. $\mathrm{MAB}$, Paris. 